IZA DP No. 4501

Credit Constraints and the Persistence of Unemployment

Nicolas Dromel

Elie Kolakez

Etienne Lehmann

October 2009 


\title{
Credit Constraints and the Persistence of Unemployment
}

\author{
Nicolas Dromel \\ CNRS, Paris School of Economics (CES), \\ Paris 1 University \\ Elie Kolakez \\ ERMES - TEPP, Paris 2 University \\ Etienne Lehmann \\ CREST, IDEP and IZA
}

\author{
Discussion Paper No. 4501 \\ October 2009
}

\author{
IZA \\ P.O. Box 7240 \\ 53072 Bonn \\ Germany \\ Phone: +49-228-3894-0 \\ Fax: +49-228-3894-180 \\ E-mail: iza@iza.org
}

\begin{abstract}
Any opinions expressed here are those of the author(s) and not those of IZA. Research published in this series may include views on policy, but the institute itself takes no institutional policy positions.

The Institute for the Study of Labor (IZA) in Bonn is a local and virtual international research center and a place of communication between science, politics and business. IZA is an independent nonprofit organization supported by Deutsche Post Foundation. The center is associated with the University of Bonn and offers a stimulating research environment through its international network, workshops and conferences, data service, project support, research visits and doctoral program. IZA engages in (i) original and internationally competitive research in all fields of labor economics, (ii) development of policy concepts, and (iii) dissemination of research results and concepts to the interested public.
\end{abstract}

IZA Discussion Papers often represent preliminary work and are circulated to encourage discussion. Citation of such a paper should account for its provisional character. A revised version may be available directly from the author. 
IZA Discussion Paper No. 4501

October 2009

\section{ABSTRACT}

\section{Credit Constraints and the Persistence of Unemployment ${ }^{*}$}

In this paper, we argue that credit market imperfections impact not only the level of unemployment, but also its persistence. For this purpose, we first develop a theoretical model based on the equilibrium matching framework of Mortensen and Pissarides (1999) and Pissarides (2000) where we introduce credit constraints. We show these credit constraints not only increase steady-state unemployment, but also slow down the transitional dynamics. We then provide an empirical illustration based on a country panel dataset of 20 OECD countries. Our results suggest that credit market imperfections significantly increase the persistence of unemployment.

JEL Classification: E24, E44, J08, J64

Keywords: credit markets, labor markets, unemployment, credit constraints, search frictions

Corresponding author:

Nicolas Dromel

Université Paris 1-MSE

106-112 boulevard de l'Hôpital

75647 Paris cedex 13

France

E-mail: nicolas.dromel@univ-paris1.fr

\footnotetext{
* The authors would like to thank participants at the Paris 1 University Macro Workshop, EEA 2009 meeting in Barcelona, EALE 2009 meeting in Tallinn and AFSE 2009 meeting in Paris, with a particular mention to Pierre Cahuc, Henri Fraisse, Thomas Le Barbanchon, Christopher Pissarides and Linas Tarasonis. The usual disclaimer applies.
} 


\section{Introduction}

An important stream of literature has dealt with the incidence of credit market imperfections on the level of unemployment (see e.g. Acemoglu (2001) or Wasmer and Weil (2004)). The underlying idea is that unemployment may be worsened by frictions outside the labor market, frictions in the credit market being one of them. However, the way credit frictions influence the transitional dynamics of unemployment remains an open question. In this paper, we argue both theoretically and empirically that credit constraints not only increase the steady-state level but also the persistence of unemployment.

Our theoretical argument is developed within a simple matching model $\grave{a}$ la Mortensen and Pissarides (1999) and Pissarides (2000). Wages are exogenous and workers lend their savings to representative banks. Building new jobs requires capital. Entrepreneurs do not have capital on their own and thereby have to borrow from banks. Absent credit market imperfections, entrepreneurs create jobs until congestion externalities in the recruiting process make job creation no longer profitable. Our departure from the standard matching model lies in the introduction of a credit constraint in the spirit of Bernanke and Gertler (1989), Kiyotaki and Moore (1997), Aghion, Banerjee and Piketty (1999) and Matsuyama (2007): entrepreneurs can only borrow a fraction of pledgeable assets. When the total value of pledgeable assets is too low, job creation is restricted. The steady state in the constrained regime is therefore characterized by higher unemployment. Moreover, as unemployment converges to its steady-state value, the number of jobs changes, affecting the total value of pledgeable assets. Through this channel, the transitional dynamics is slowed down, and unemployment becomes more persistent. In a simulation exercise, we show that the convergence towards the steady-state employment level is at least twice slower in a credit constrained economy.

To illustrate this mechanism, we perform an empirical exercise on a panel of 20 OECD countries, over the 1982-2003 period. Data were drawn from Bassanini and Duval (2006) for the labor market institutions and Beck, Demirgüç-Kunt and Levine (2000) for financial development variables. We approximate the stringency of credit constraints by the ratio of private credit by deposit money banks and other financial institutions as a percentage of GDP. The lower this ratio, the more credit constrained the economy. We provide estimations of the unemployment level where we control for the effects of the one period lagged unemployment and the traditional labor market factors. ${ }^{1}$ We find that more stringent credit constraints are associated with higher unemployment. Moreover, we find a significantly negative impact of the interaction between lagged unemployment and our mesure of the stringency of credit constraints. This suggests that credit constraints not only increase the level but also the persistence of unemployment.

Our contribution follows the literature on the macroeconomic consequences of credit market

\footnotetext{
${ }^{1}$ These variables are: the average unemployment benefit replacement rate, the tax wedge, the employment protection legislation index, the union density index, the degree of coordination of wage bargaining, the product market regulation index and the output gap.
} 
frictions. The seminal papers of Bernanke and Gertler (1989) and Kiyotaki and Moore (1997) explain how credit market frictions amplify business cycle fluctuations through a financial accelerator mechanism. Adopting a longer run perspective, Aghion, Banerjee and Piketty (1999) and Matsuyama (2007) argue that credit market frictions may generate nonlinear dynamics such as credit traps, credit collapse, endogenous credit cycles or growth miracles. However, these papers assume away labor market imperfections, and in particular those generating unemployment. Acemoglu (2001) suggests that the difference in credit markets frictions between Europe and the US can contribute to explain the difference in unemployment patterns. In his model, credit frictions influence the economic outcome through the choice of becoming an entrepreneur. In our model, credit frictions influence more specifically the volume of credit devoted to job creation. Wasmer and Weil (2004) introduce search frictions in both the labor and credit markets. Their focus is on the complementarity between the two frictions, not upon the transitional dynamics. Hristov (2009) calibrates a Dynamic Stochastic General Equilibrium model with search frictions on the labor market, New-Keynesian price staggering and credit frictions due to a costly state verification problem. Simulations show that the introduction of credit frictions magnifies the propagation of shocks and increase the volatility of unemployment.

Our empirical exercise is in line with the literature that investigates the determinants of unemployment time patterns in OECD countries (see e.g., Blanchard and Wolfers (2000), Nickell, Nunziata and Ochel (2005), Belot and Van Ours (2004), Bassanini and Duval (2006), Bertola, Blau and Kahn (2007)). In a recent paper, Gatti and Vaubourg (2009) try to assess the impact of credit market imperfections on the level of unemployment. We depart from their work by analyzing also the effect of credit development on the persistence of unemployment.

The remainder of this paper proceeds as follows. The theoretical model is exposed in Section II. Section III studies the properties of the steady state and of the transitional dynamics. Section IV provides an empirical illustration of the impact of credit frictions on unemployment persistence. Some concluding comments and directions for further research are gathered in section V.

\section{The model}

We focus on the macroeconomic consequences of credit market frictions. For that purpose, we develop a theoretical model with very simple forms of credit frictions and of the credit contract. Following Wasmer and Weil (2004), we assume that agents are exogenously and perfectly segmented between three categories: workers, entrepreneurs (or equivalently in our economy "managers") and banks (or equivalently in our economy "financiers"). ${ }^{2}$ All agents

\footnotetext{
${ }^{2}$ Bernanke and Gertler (1989), Kiyotaki and Moore (1997) and Aghion et al. (1999) also assume a form of exogenous separations between entrepreneurs and financiers in the credit market. The distinction between "banks" and "financiers" is only meaningful if one wants to investigate the form of the credit contract, which is beyond the scope of the present paper.
} 
however have the same preferences. They are risk neutral and discount future at rate $\rho>0$ over an infinite horizon. Time is continuous.

Workers are either employed or unemployed. Employed workers receive wage $w>0$. This wage is assumed exogenous, a simplification whose implications will be discussed later on. Unemployed workers search for jobs and receive no income. All workers deposit their savings in banks. Since they are risk neutral, their savings are infinitely elastic in the interest rate. Hence the deposit rate equals their discount rate $\rho>0$.

Entrepreneurs have no personal wealth, but have the ability to create and manage a large number of jobs. The creation of a new job requires a once-for-all investment of $k>0$ units of capital that entrepreneurs have to borrow from banks. Once created, vacant jobs become productive only after finding a suitable worker to hire, which takes time. A filled job produces a flow $y>w$ of output. Entrepreneurs divide these flows between their own consumption, wages paid to employed workers and interests $r \cdot k$ to banks. Finally, jobs are exogenously destroyed at rate $\delta>0$, in which case the initial capital $k$ is dissolved.

The deposit rate is $\rho$, while the lending rate $r>0$ is continuously renegotiated. Competition among banks is perfect so they make no profit.

\section{II.1 The matching process}

Let $L$ be the number of employed workers. $L$ also equals the number of filled jobs. The total mass of workers is normalized to 1 , so there are $1-L$ unemployed workers searching for a job. Let $V$ be the (endogenous) number of vacant jobs. Entrepreneurs search for suitable workers to fill their vacancies, which is time-consuming. Instead of describing in details these search activities, we summarize the macroeconomic outcome of the matching process by a function $Q(1-L, V)$ that expresses the flow of hiring per unit of time as a function of the numbers of unemployed workers and vacancies (Diamond (1982), Mortensen and Pissarides (1999), Pissarides (2000)). We assume $Q(.,$.$) is increasing and concave with respect to both arguments and exhibits constant$ returns to scale. ${ }^{3}$ We in addition assume $Q(.,$.$) is continuously differentiable over \mathbb{R}_{+}^{2}$.

Let $\theta=V /(1-L)$ denote the tightness on the labor market. The rate at which a vacancy meets a worker is given by $Q(1-L, V) / V=Q(1 / \theta, 1) \stackrel{\text { def }}{\equiv} q(\theta)$. From the assumptions we made about the matching function, we deduce that $q($.$) is a decreasing and differentiable$ function of $\theta$. Symmetrically, the rate at which an unemployed worker exits unemployment is $Q(1-L, V) /(1-L)=\theta q(\theta)$. This rate is an increasing and differentiable function of $\theta$. Jobs are dissolved exogenously at rate $\delta>0$ for sake of simplicity. The evolution of the employment level (the number of filled jobs) is driven by the difference between employment inflows and outflows:

$$
\dot{L}=\theta q(\theta) \cdot(1-L)-\delta \cdot L
$$

\footnotetext{
${ }^{3}$ See Petrongolo and Pissarides (2001).
} 
In steady state, this defines the Beveridge curve

$$
L=\frac{\theta q(\theta)}{\delta+\theta q(\theta)}
$$

This curve, labelled (BC) hereafter, is upward-sloping and convex in the $(L, \theta)$ plan (see Figures 1 and 2). When the economy lies on the left (resp. on the right) of the $\mathrm{BC}$ curve, the employment level is low (high) so employment outflows are lower (higher) than inflows. Consequently $L$ increases (decreases), so the economy moves rightwards (leftwards).

\section{II.2 Entrepreneurs}

A filled job produces a flow $y$ of goods, costs a flow $w$ of wages and $r \cdot k$ of reimbursement to banks. The value $J$ of a filled job for an entrepreneur verifies the asset equation:

$$
\rho \cdot J=y-w-r \cdot k-\delta \cdot J+\dot{J}
$$

A vacant job neither yields cost nor gain. It is filled at the Poisson rate $q(\theta)$. The value $J^{\mathrm{v}}$ of a vacancy thus verifies the asset equation:

$$
\rho \cdot J^{\mathrm{v}}=q(\theta)\left(J-J^{\mathrm{v}}\right)+\dot{J}^{\mathrm{v}}
$$

\section{II.3 Banks}

When a bank is in contact with a filled job, it receives a flow $r \cdot k$ of reimbursement. Since the job is dissolved at the Poisson rate $\delta>0$ and the bank finances itself at rate $\rho$, the value $B$ for a bank to be in contact with a filled job verifies the asset equation

$$
\rho \cdot B=r \cdot k-\delta \cdot B+\dot{B}
$$

When a bank is in contact with a vacant job, the latter is unable to pay back its debt until the job becomes filled. Therefore, the value $B^{\mathrm{v}}$ of a bank to be in contact with a vacant job verifies:

$$
\rho \cdot B^{\mathrm{v}}=q(\theta)\left(B-B^{\mathrm{v}}\right)+\dot{B}^{\mathrm{v}}
$$

Perfect competition in the banking sector decreases the lending interest rate $r$ until the zeroprofit condition $B^{\mathrm{v}}-k=0$ in the banking sector is met. This last condition pins down $B^{\mathrm{v}}=k$ and $\dot{B}^{\mathrm{v}}=0$. Therefore, the interest rate adjusts so that, at each point in time:

$$
B=k\left(1+\frac{\rho}{q(\theta)}\right)
$$

Summing (3) and (5) gives

$$
(\rho+\delta)(J+B)=y-w+\dot{J}+\dot{B}
$$

$J+B$ equals the total value of a filled job for the bank and the entrepreneur. It yields a constant profit that equals output $y$ minus wage $w$ and is dissolved at rate $\delta$. This equation featuring forward-looking variables is unstable. Assuming away bubbles implies at each point in time:

$$
J+B=\frac{y-w}{\rho+\delta}
$$




\section{The Equilibrium}

There are two conditions on the job creation.

1. Assume that creating a vacant job induces a once-for-all disutility cost $c \geq 0$. The net gain of creating a job should be nonnegative, so $J^{\mathrm{v}} \geq c$. If this constraint is binding, then $J^{\mathrm{v}}=c$ permanently and $\dot{J}^{\mathrm{v}}=0$. Using (4) implies that at each point in time

$$
J=c\left(1+\frac{\rho}{q(\theta)}\right)
$$

This expression combined with (7) and (8) gives :

$$
\frac{y-w}{\rho+\delta}=(c+k)\left(1+\frac{\rho}{q(\theta)}\right)
$$

When this condition is binding, it defines a tightness level independently of the employment level, as in Mortensen and Pissarides (1999). Hence in the $(L, \theta)$ plan, this curve is horizontal. Below, tightness is lower, so $J^{v}$ is higher than $c$ and entrepreneurs want to create more vacancies.

2. The second condition comes from the fact that creditors value their loans even in the case where entrepreneurs deviate from their on-equilibrium behavior. Indeed, the job value in case of default is crucial since it affects the amount of credit banks agree to provide. There may be different contracting frictions between banks and entrepreneurs that may explain why default values matter. ${ }^{4}$ Discussing these is beyond the scope of our paper. When entrepreneurs default, we assume banks become managers of the jobs. However, they have a much lower ability in that activity compared to entrepreneurs and have a comparative disadvantage in hiring workers with respect to managing filled jobs. To study in the simplest possible way the consequences of this type of credit frictions on unemployment dynamics, we assume the maximum level of credit $k(V+L)$ that can be supplied in the economy equals a fraction $1 / \mu$ of what banks get in case of default. The latter amount is nothing else than the total value of filled jobs $L \cdot(J+B)$. Hence,

$$
\mu \cdot L \cdot(J+B) \geq k(V+L) \quad \text { where } \mu \geq 1
$$

The higher $\mu$, the less stringent the credit market. In the limit case where $\mu$ tends to infinity, entrepreneurs are not credit constrained any longer. Using $V=\theta(1-L)$ and (8), the credit constraint when binding implies at each point in time:

$$
\theta=\left(\frac{\mu}{k} \frac{y-w}{\rho+\delta}-1\right) \frac{L}{1-L}
$$

\footnotetext{
${ }^{4}$ These frictions can be justified by the possibility of strategic default by the entrepreneur, renegotiations, moral hazard, costly state verification and so on.
} 
Whenever (9) and (10) do not bind, entrepreneurs find profitable to create additional vacancies and are able to borrow additional credit. The number of vacancies then instantaneously rises, pushing tightness $\theta$ upwards. Entrepreneurs thus create vacancies until one of the two constraints binds. So one must have at each point in time:

$$
\theta=\min \left[q^{-1}\left(\frac{\rho(c+k)(\rho+\delta)}{(y-w)-((c+k)(\rho+\delta))}\right) ;\left(\frac{\mu}{k} \frac{y-w}{\rho+\delta}-1\right) \frac{L}{1-L}\right]
$$

The first term in the right-hand side does not depend upon employment, while the second increases with employment. Therefore, in the $(L, \theta)$ map, Equation (11) can be depicted by a curve which is first increasing (corresponding to the constrained regime) and then horizontal (corresponding to the unconstrained regime) (See the curves labeled JC in Figures 1, 2 and 3).

If the credit constraint (10) is not binding, Equation (9) holds with equality, which determines $\theta$ at each point in time, thereby at the steady state. Then the level of employment converges to its stationary value according to (1) in an auto-regressive fashion. The speed of convergence is given by $\delta+\theta q(\theta)$.

Assume now that the credit constraint is binding. Equation (10) then defines an upwardsloping and convex relationship in the $(L, \theta)$ map, which tends to 0 as $L$ tends to 0 and tends to $\infty$ when the economy converges to full employment. At a credit-constrained steady state, using (2) to substitute $L$ in (10) leads to

$$
\frac{\delta}{q(\theta)}=\frac{\mu}{k} \frac{y-w}{\rho+\delta}-1
$$

The left-hand side of (12) increases in $\theta$, so this equation admits at most ${ }^{5}$ one solution in $\theta$. Moreover, at this solution, tightness $\theta$ increases with productivity $y$ and the parameter $\mu$ of the financial constraint, and decreases with wage $w$ and capital $k$.

In Figures 1, 2 and 3, the steady-state of the economy corresponds to an intersection between the $\mathrm{BC}$ curve and the increasing part of JC curve. When productivity $y$ increases or when wage $w$ and capital $k$ decrease, the JC curve shifts upwards, as depicted in Figure 1. When financial market improves (so that $\mu$ increases), only the increasing part of the JC curve shifts upwards, as illustrated by Figure 2. When the disutility $\operatorname{cost} c$ for the entrepreneur of creating an additional vacancy decreases, only the flat part of the JC curve shifts upwards, as illustrated by Figure 3. To be consistent with the comparative statics properties of the credit-constrained steady state defined by Equation (12), the BC curve has to be steeper than the increasing part of the JC curve. At an intersection between the $\mathrm{BC}$ curve and the JC curve, the former is always steeper, whether or not the intersection corresponds to the credit-constrained part of the JC curve. This

\footnotetext{
${ }^{5}$ Recall that $q($.$) is decreasing in \theta$ over $\mathbb{R}_{*}^{+}$. Let us denote $\underline{q}=\lim _{\theta \mapsto \infty} q(\theta)$ and $\bar{q}=\lim _{\theta \mapsto 0} q(\theta)$, with $0 \leq \underline{q}<\bar{q} \leq$ $+\infty$. There exists a solution if and only if

$$
\frac{\delta}{\bar{q}}<\frac{\mu}{k} \frac{y-w}{\rho+\delta}-1<\frac{\delta}{\underline{q}}
$$

where it is understood that $\delta / \underline{q}=+\infty$ if $\underline{q}=0$ and $\delta / \bar{q}=0$ if $\bar{q}=+\infty$.
} 


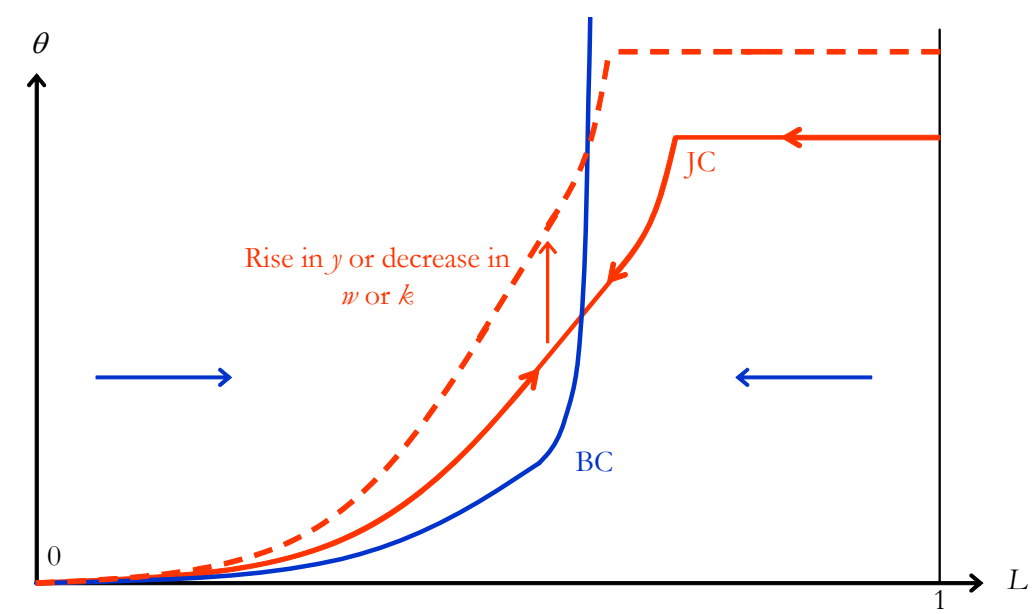

Figure 1: Comparative statics in $y, w$ and $k$ and steady-state stability.

has two consequences. First, apart from the trivial $L=\theta=0$ steady state, there exists at most ${ }^{6}$ one steady-state equilibrium. Second, since the economy lies at each point in time along the JC curve, the non-trivial steady state is dynamically stable, as shown by the Figures 1, 2 and 3.

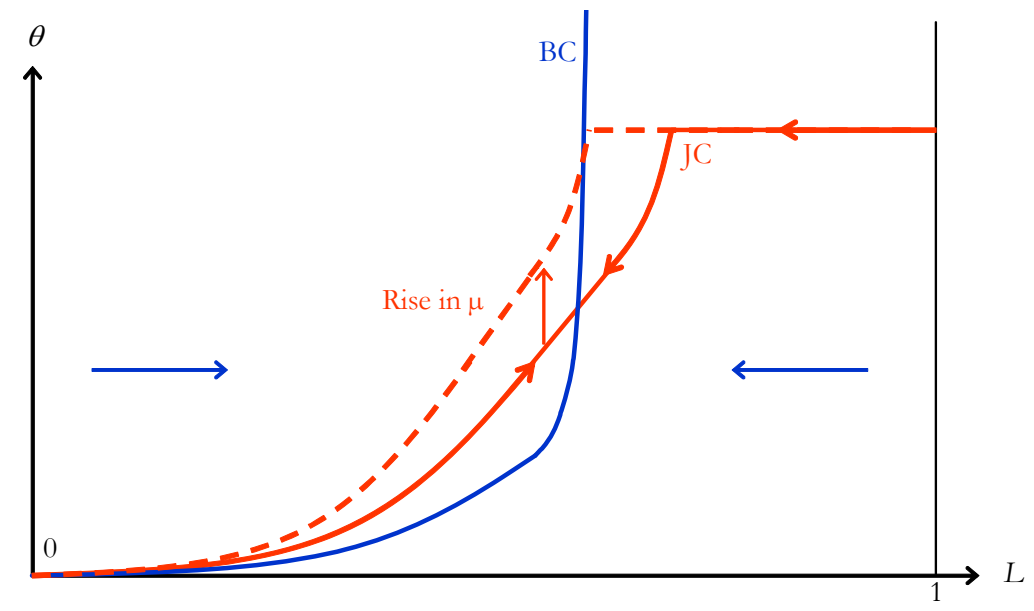

Figure 2: Comparative statics in $\mu$

We now examine whether unemployment is more or less persistent when the credit constraint (10) is binding. Since the job creation condition under credit constraint (10) holds at each point in time, plugging (10) into (1) leads to (see Appendix A):

$$
\frac{\partial \dot{L}}{\partial L}=-(\delta+\theta q(\theta))+(1-\eta(\theta)) \cdot \frac{\theta q(\theta)}{L}
$$

${ }^{6}$ To ensure existence, one has to assume in addition to the conditions given in Footnote 5 , that

$$
\frac{y-w}{\rho+\delta}>(c+k)\left(1+\frac{\rho}{\bar{q}}\right)
$$

This further restriction ensures the existence of a tightness level such that job creation is profitable and the horizontal part of the JC curve is above the horizontal axis. 


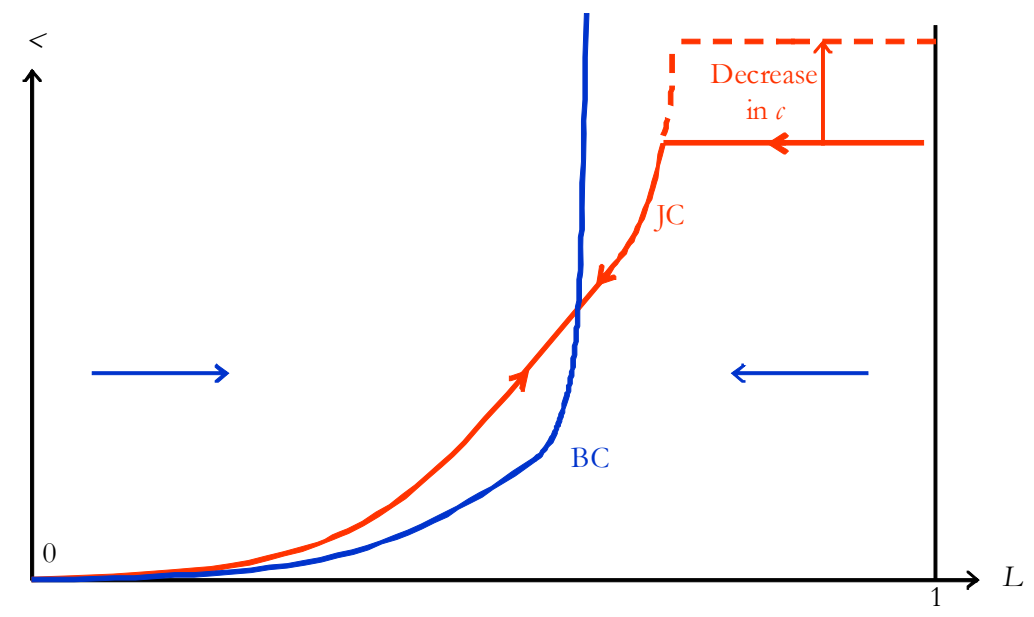

Figure 3: Comparative statics in $c$

where $\eta(\theta)=-\theta q^{\prime}(\theta) / q(\theta) \in(0,1)$ denotes the elasticity of the matching function $Q(.,$.$) with$ respect to the stock of unemployment. Using (2) around a steady state leads to:

$$
\frac{\partial \dot{L}}{\partial L}=-\eta(\theta) \cdot(\delta+\theta q(\theta))
$$

Thus, employment converges at a lower rate to its steady-state value when the economy is credit constrained. To understand why, let us denote by $L^{*}(\theta)=\theta q(\theta) /(\delta+\theta q(\theta))$ the level of employment which equilibrates labor inflows and outflows, conditional on a tightness level. When tightness $\theta$ is constant, which is the case in the unconstrained regime, employment converges in an autoregressive fashion towards its stationary target $L^{*}(\theta)$. Conversely, in the constrained regime, tightness $\theta$ increases in $L$, as a rise in employment increases the stock of secured assets in case of default. Then, when employment is below (above) the $L^{*}(\theta)$ target, employment increases (decreases) for the same "flow-rebalancing" reason as in the unconstrained regime. However, this increase (decrease) in turn implies an increase (decrease) of the $L^{*}(\theta)$ target. As a matter of fact, the convergence towards the steady state is delayed, explaining why employment will converge at a slower pace in the constrained regime.

To fix ideas on how much important is the persistence difference between the two regimes, we notice that around the steady state, the speed of convergence is given by $\delta+\theta q(\theta)$ in the unconstrained regime and $\eta(\theta)(\delta+\theta q(\theta))$ in the constrained regime. According to Petrongolo and Pissarides (2001), $\eta(\theta)=0.5$ is the most plausible value for the elasticity of the matching function. Hence, the speed of convergence towards the same steady state (i.e. with the same $\theta$ ) would be twice smaller under credit constraints. Moreover, since the constrained regime is associated with lower values of tightness, the speed of convergence would be even slower. A little calibration exercise can illustrate this reasoning. We consider two economies with the same given level of initial employment and the same calibrated steady-state employment. The first economy is credit-constrained in the sense that vacancy creation is driven by (10). The second economy 
is not credit constrained, so that tightness is permanently at its steady-state level given by (9). We then compare the transitional dynamics of employment in the two economies.

The calibration exercises are done on an annual basis, and aim at matching the french economy. The matching function is assumed to be of the following symmetric Cobb-Douglas specification: $Q=A(1-L)^{\frac{1}{2}} V^{\frac{1}{2}}$. The job destruction rate is set at $\delta=0.10$, so the average duration of employment is 10 years. Targeting a steady-state unemployment level of $9 \%$ and an average vacancy duration of 6 weeks (Maillard 1997) gives the scaling parameter of the matching function $A=0.34$ and the steady-state tightness $\theta^{*}=8.76$. Using (12) implies $\frac{\mu}{k} \frac{y-w}{\rho+\delta}-1=0.866$. We then simulate transitional dynamics by solving (1). In the credit-constrained case, tightness is given by $\theta=0.866 \frac{L}{1-L}$ according to (10), whereas in the absence of credit constraints, tightness is permently set at its steady-state value $\theta^{*}=8.76$.
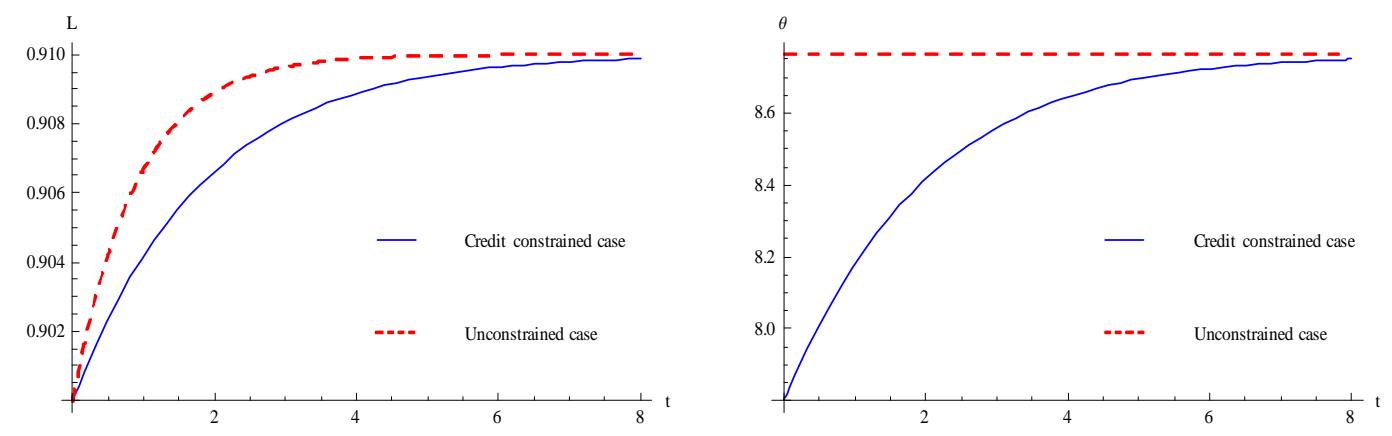

Figure 4: Simulated transitional dynamics

Figure 4 displays the transitional dynamics of employment $L$ and tightness $\theta$ for these two economies, starting from an initial unemployment of $10 \%$ (i.e., $L$ inially equals 0.90 ). It takes about 8 years for tightness in the credit-constrained economy (solid line) to reach its steady state. While it takes about 1,5 year in the unconstrained economy (dashed lines) to achieve $4 / 5^{\text {th }}$ of the adjustment, the corresponding delay is about 3 years in the constrained economy. This ratio with a magnitude order of 0.5 matches our previous theoretical finding: the ratio between speeds of convergence around the steady state equals the elasticity of the matching function.

In this exercise, we have assumed that wages are fixed at an exogenous level $w$. In an endogenous wage setting framework, wages would typically be increasing in tightness (See e.g. Pissarides 2000). Hence, wages would be constant along transitional dynamics of the unconstrained economy. In the constrained case, wage would presumably increase along transitional dynamics, thereby decelerating even further the adjustment of tightness and employment. This suggests that endogenizing the wage setting would reinforce our mechanism.

We are therefore confident that credit constraints have an important quantitative impact on unemployment persistence. 


\section{Empirics}

In this section we investigate empirically, on macro-panel data, the impact of credit market imperfections on the level and persistence of unemployment. The analysis is carried out on 20 OECD countries ${ }^{7}$ over the period 1982-2003. Data were drawn from Bassanini and Duval (2006) for the labor market institutions and Beck et al. (2000) for financial development variables. ${ }^{8}$

\section{IV.1 Estimated models}

To test whether credit market imperfections increase unemployment persistence, we compare the estimates of the following five equations. ${ }^{9}$

$$
\begin{aligned}
U R_{i, t}= & \alpha U R_{i, t-1}+\kappa X_{i, t}+\nu_{i}+\lambda_{t}+\varepsilon_{i, t} \\
U R_{i, t}= & \beta C R E_{i, t}+\kappa X_{i, t}+\nu_{i}+\lambda_{t}+\varepsilon_{i, t} \\
U R_{i, t}= & \alpha U R_{i, t-1}+\beta C R E_{i, t}+\kappa X_{i, t}+\nu_{i}+\lambda_{t}+\varepsilon_{i, t} \\
U R_{i, t}= & \alpha U R_{i, t-1}+\beta C R E_{i, t}+\gamma \widehat{C R E}_{i, t} \times \widehat{U R}_{i, t-1} \\
& +\kappa X_{i, t}+\nu_{i}+\lambda_{t}+\varepsilon_{i, t} \\
U R_{i, t}= & \alpha U R_{i, t-1}+\beta C R E_{i, t}+\gamma \widehat{C R E}_{i, t} \times \widehat{U R}_{i, t-1} \\
& +\psi \widehat{E P L}_{i, t} \times \widehat{U R}_{i, t-1}+\kappa X_{i, t}+\nu_{i}+\lambda_{t}+\varepsilon_{i, t}
\end{aligned}
$$

where $U R_{i t}$ is the aggregate rate of unemployment, $U R_{i, t-1}$ the lagged rate of unemployment and $X_{i, t}$ is a vector of standard unemployment determinants in the literature. It here includes the average unemployment benefit replacement rate $(A R R)$, the degree of coordination of wage bargaining $(C O R P)$, the union membership rates $(U N D E N S)$, the tax wedge $(T W)$, the degree of employment protection legislation $(E P L)$, the average degree of stringency of product market regulation $(P M R)$, and the OECD measure of output gap $(O G A P)$ which particularly aims at controlling for the unemployment effects of aggregate demand fluctuations over the business cycle (see e.g., Bassanini and Duval (2006)). Country-fixed effects $\nu_{i}$ capture unobserved heterogeneity between countries, while time-fixed effects $\lambda_{t}$ control for world trends and business cycle effects.

Equation (14a) is our benchmark where unemployment is only explained by its lagged value and other standard determinants in the literature. The coefficient $\alpha$ of the lagged value is therefore an empirical measure of unemployment persistence.

We capture in Equation (14c) the effect of the credit market development on the level of unemployment by introducing an indicator of the stringency of credit constraints: the share of private credit by deposit money banks and other financial institutions to GDP $(C R E)$. It

\footnotetext{
${ }^{7}$ Australia, Austria, Belgium, Canada, Denmark, Finland, France, Germany, Ireland, Italy, Japan, Netherlands, Norway, New Zealand, Portugal, Spain, Sweden, Switzerland, United Kingdom, United States.

${ }^{8}$ The definitions and description of the variables are in Appendix B.

${ }^{9}$ The constant term is here implicitely included either in the country-specific effects, or in the time-specific effects.
} 
measures isolated credit issued to the private sector as opposed to credit issued to governments and public enterprises. Furthermore, it concentrates on credit issued by intermediaries other than the central bank. It is a measure of the activity of financial intermediaries in one of its main function: channeling savings to investors. The higher this indicator, the less stringent credit constraints. The ranking of countries' credit development according to this variable is available in Appendix C. Credit market frictions may have a steady-state effect on unemployment which is captured by coefficient $\beta$. As credit and lagged unemployment variables may be strongly correlated, we use Equation (14b) to assess how parameters in Equation (14c) are affected when lagged unemployment is dropped.

We introduce in Equation (14d) an interaction term between credit market imperfection and lagged unemployment. Let $\overline{U R}$ and $\overline{C R E}$ be respectively the means of unemployment rates and of the share of private credit by deposit money banks and other financial institutions to GDP over the whole sample. We define $\widehat{U R}_{i, t-1}=U R_{i, t-1}-\overline{U R}$ and $\widehat{C R E}_{i, t}=C R E_{i, t}-\overline{C R E}$ as the deviations from the mean of these two variables. The coefficient $\gamma$ thus specifically captures how credit market imperfections influence unemployment persistence, net of their effects on steadystate unemployment. As a matter of fact, Equation (14d) is the central one for our empirical analysis.

Finally, we evaluate in Equation (14e) how parameters in Equation (14d) are affected when the influence of employment protection legislation on unemployment persistence (captured by $\psi$ ) is also taken into account. Indeed, we theoretically (cf. Pissarides 2000 ) expect $E P L$ to reduce both employment inflows and outflows. Equation (14e) therefore verifies whether estimates of $\gamma$ in (14d) do not spuriously capture the effect of EPL.

Since we exploit similar OECD data for labor market institutions, we follow Bassanini and Duval (2006) and use the Generalized Least Square estimation method allowing for heteroscedastic errors. Doing so, we are also consistent with the methodology of Nickell et al. (2005), on a different set of data.

Institutional variables $X_{i, t}$ and $C R E_{i, t}$ are time-varying. Changes in unemployment may cause potential policy reactions that would affect these variables. Because causality may run on both directions, these regressors may be correlated with the error term, generating simultaneous biases. To deal with these econometric issues we also adopt an instrumental approach, estimating our central Equation (14d) using both the standard Two-Stage Least Squares method, and the Arellano-Bond (1991) difference GMM estimator.

\section{IV.2 Main results}

The main results of our estimations are displayed in Table 1. We first note that the estimated coefficient $\alpha$ for the one-period lagged unemployment variable $\left(U R_{i, t-1}\right)$ is significantly different from zero at the $1 \%$ level with the expected positive sign, suggesting a strong persistence of 
Table 1: Empirical results

\begin{tabular}{|c|c|c|c|c|c|}
\hline \multirow[b]{2}{*}{ Specifications } & \multicolumn{5}{|c|}{ Dependent Variable: $U R_{i, t}$} \\
\hline & $(14 \mathrm{a})$ & $(14 \mathrm{~b})$ & $(14 \mathrm{c})$ & $(14 d)$ & $(14 \mathrm{e})$ \\
\hline$U R_{i, t-1}$ & $\begin{array}{c}0.77^{* * *} \\
(38.80)\end{array}$ & & $\begin{array}{c}0.77^{* * *} \\
(37.36)\end{array}$ & $\begin{array}{c}0.74^{* * *} \\
(32.95)\end{array}$ & $\begin{array}{c}0.74^{* * *} \\
(33.44)\end{array}$ \\
\hline$C R E_{i, t}$ & & $\begin{array}{c}-1.41^{* * *} \\
(-3.72)\end{array}$ & $\begin{array}{l}-0.01 \\
(-0.05)\end{array}$ & $\begin{array}{c}-0.42^{*} \\
(-1.91)\end{array}$ & $\begin{array}{l}-0.35 \\
(-1.55)\end{array}$ \\
\hline$\widehat{C R E}_{i, t} \times \widehat{U R}_{i, t-1}$ & & & & $\begin{array}{c}-0.12^{* * *} \\
(-3.27)\end{array}$ & $\begin{array}{c}-0.11^{* * *} \\
(-2.74)\end{array}$ \\
\hline$\widehat{E P L}_{i, t} \times \widehat{U R}_{i, t-1}$ & & & & & $\begin{array}{c}0.056^{* * *} \\
(3.37) \\
\end{array}$ \\
\hline$A R R_{i, t}$ & $\begin{array}{c}0.018^{* *} \\
(1.97)\end{array}$ & $\begin{array}{c}0.12^{* * *} \\
(6.73)\end{array}$ & $\begin{array}{c}0.017^{*} \\
(1.93)\end{array}$ & $\begin{array}{c}0.023^{* * *} \\
(2.62)\end{array}$ & $\begin{array}{c}0.041^{* * *} \\
(3.85)\end{array}$ \\
\hline$C O R P_{i, t}$ & $\begin{array}{c}-0.69^{* * *} \\
(-3.14)\end{array}$ & $\begin{array}{c}-2.34^{* * *} \\
(-6.13)\end{array}$ & $\begin{array}{c}-0.69^{* * *} \\
(-3.12)\end{array}$ & $\begin{array}{c}-0.77^{* * *} \\
(-3.44)\end{array}$ & $\begin{array}{c}-0.99^{* * *} \\
(-4.23)\end{array}$ \\
\hline$U N D E N S_{i, t}$ & $\begin{array}{l}0.014 \\
(1.54)\end{array}$ & $\begin{array}{l}0.012 \\
(0.67)\end{array}$ & $\begin{array}{l}0.014 \\
(1.51)\end{array}$ & $\begin{array}{c}0.008 \\
(0.89)\end{array}$ & $\begin{array}{c}0.016^{*} \\
(1.66)\end{array}$ \\
\hline$T W_{i, t}$ & $\begin{array}{c}0.024^{*} \\
(1.78)\end{array}$ & $\begin{array}{c}0.2^{* * *} \\
(6.99)\end{array}$ & $\begin{array}{c}0.024^{*} \\
(1.66)\end{array}$ & $\begin{array}{c}0.032^{* *} \\
(2.25)\end{array}$ & $\begin{array}{l}0.039^{* * *} \\
(2.70)\end{array}$ \\
\hline$E P L_{i, t}$ & $\begin{array}{c}-0.41^{* * *} \\
(-2.62)\end{array}$ & $\begin{array}{c}-0.66^{* *} \\
(-1.99)\end{array}$ & $\begin{array}{c}-0.40^{* *} \\
(-2.57)\end{array}$ & $\begin{array}{c}-0.51^{* * *} \\
(-3.09)\end{array}$ & $\begin{array}{c}-0.53^{* * *} \\
(-3.37)\end{array}$ \\
\hline$P M R_{i, t}$ & $\begin{array}{c}0.17^{* *} \\
(2.09)\end{array}$ & $\begin{array}{c}0.56^{* * *} \\
(2.94)\end{array}$ & $\begin{array}{c}0.17^{* *} \\
(2.06)\end{array}$ & $\begin{array}{c}0.21^{* * *} \\
(2.59)\end{array}$ & $\begin{array}{c}0.17^{* *} \\
(2.10)\end{array}$ \\
\hline$O G A P_{i, t}$ & $\begin{array}{c}-0.21^{* * *} \\
(-11.97) \\
\end{array}$ & $\begin{array}{c}-0.44^{* * *} \\
(-12.90) \\
\end{array}$ & $\begin{array}{c}-0.21^{* * *} \\
(-11.83) \\
\end{array}$ & $\begin{array}{c}-0.21^{* * *} \\
(-12.37) \\
\end{array}$ & $\begin{array}{c}-0.21^{* * *} \\
(-11.75) \\
\end{array}$ \\
\hline Instruments & No & No & No & No & No \\
\hline Time dummies & Yes & Yes & Yes & Yes & Yes \\
\hline Country dummies & Yes & Yes & Yes & Yes & Yes \\
\hline Observations & 369 & 369 & 369 & 369 & 369 \\
\hline
\end{tabular}

Estimate coefficients are significant at the $1 \%$ level if ***, $5 \%$ if **, $10 \%$ if *. Student T-statistics are given in brackets beneath the coefficients.

Nota: $\overline{U R}$ and $\overline{C R E}$ respectively stand for the means of $U R_{i, t-1}$ and $C R E_{i, t}$ 
Table 2: Instrumentation Equation (14 d)

\begin{tabular}{|c|c|c|c|}
\hline & \multicolumn{3}{|c|}{ Dependent Variable: $U R_{i, t}$} \\
\hline & \multirow[b]{2}{*}{ GLS } & \multicolumn{2}{|c|}{ Instrumental Variables estimates } \\
\hline & & $2 \mathrm{SLS}$ & Arellano-Bond difference GMM \\
\hline$\overline{U R_{i, t-1}}$ & $\begin{array}{l}0.74^{* * *} \\
(32.95)\end{array}$ & $\begin{array}{c}0.66^{* * *} \\
(10.90)\end{array}$ & $\begin{array}{c}0.63^{* * * *} \\
(11.30)\end{array}$ \\
\hline$C R E_{i, t}$ & $\begin{array}{l}-0.42^{*} \\
(-1.91)\end{array}$ & $\begin{array}{l}-1.12^{*} \\
(-1.71)\end{array}$ & $\begin{array}{l}-1.20^{*} \\
(-1.87)\end{array}$ \\
\hline$\widehat{C R E}_{i, t} \times \widehat{U R}_{i, t-1}$ & $\begin{array}{c}-0.12^{* * *} \\
(-3.27)\end{array}$ & $\begin{array}{c}-0.52^{* *} \\
(-2.48)\end{array}$ & $\begin{array}{c}-0.27^{* * *} \\
(-3.05)\end{array}$ \\
\hline$A R R_{i, t}$ & $\begin{array}{c}0.023^{* * *} \\
(2.62)\end{array}$ & $\begin{array}{c}0.02 \\
(1.60)\end{array}$ & $\begin{array}{l}0.018 \\
(1.04)\end{array}$ \\
\hline$C O R P_{i, t}$ & $-0.77^{* * *}$ & $-0.65^{* *}$ & $-1.66^{* * *}$ \\
\hline$U N D E N S_{i, t}$ & $\begin{array}{l}0.008 \\
(0.89)\end{array}$ & $\begin{array}{l}-0.008 \\
(-0.62)\end{array}$ & $0.15^{* * * *}$ \\
\hline$T W_{i, t}$ & $0.032^{* *}$ & $0.065^{* * *}$ & 0.011 \\
\hline$E P L_{i, t}$ & $-0.51^{* * *}$ & $-0.64^{* *}$ & $\begin{array}{l}1.22^{* *} \\
(2.10)\end{array}$ \\
\hline$P M R_{i, t}$ & $0.21^{* * *}$ & $0.32^{* *}$ & -0.28 \\
\hline$O G A P_{i, t}$ & $\begin{array}{c}-0.21^{* * *} \\
(-12.37)\end{array}$ & $\begin{array}{c}-0.24^{* * *} \\
(-8.72)\end{array}$ & $\begin{array}{c}-0.30^{* * *} \\
(-11.69)\end{array}$ \\
\hline Instruments & No & Yes & Yes \\
\hline Time dummies & Yes & Yes & Yes \\
\hline Country dummies & Yes & No & No \\
\hline $\begin{array}{c}\text { Sargan overidentification test } \\
\text { Statistic } \\
\text { p-value }\end{array}$ & & $\begin{array}{l}0.58 \\
0.75\end{array}$ & $\begin{array}{c}89.61 \\
0.14\end{array}$ \\
\hline $\begin{array}{l}\text { Arellano-Bond test for autocorrelation } \\
\qquad \begin{array}{c}\text { Order } 1 \\
\text { p-value }\end{array}\end{array}$ & & & $\begin{array}{l}-3.64 \\
0.0003\end{array}$ \\
\hline $\begin{array}{l}\text { Order } 2 \\
\text { p-value }\end{array}$ & & & $\begin{array}{c}-1.20 \\
0.84\end{array}$ \\
\hline Observations & 369 & 369 & 369 \\
\hline
\end{tabular}

Estimate coefficients are significant at the $1 \%$ level if ***, $5 \%$ if **, $10 \%$ if *.

Student T-statistics are given in brackets beneath the coefficients.

Nota: $\overline{U R}$ and $\overline{C R E}$ respectively stand for the means of $U R_{i, t-1}$ and $C R E_{i, t}$

\section{SLS estimation:}

Instrumented variables : $C R E_{i, t}$ and $\widehat{C R E}_{i, t} \times \widehat{U R}_{i, t-1}$

Instruments : $C R E_{i, t-1}, C R E_{i, t-2}, P U B O W N_{i, t-1}, P M R_{i, t-2}, U R_{i, t-1}, A R R_{i, t}, C O R P_{i, t}, U N D E N S_{i, t}$, $T W_{i, t}, E P L_{i, t}, P M R_{i, t}, O G A P_{i, t}$ and country dummies

\section{Arellano-Bond difference GMM estimation:}

GMM-type instruments: $U R_{i, t-3}, C R E_{i, t-1}, C R E_{i, t-2},\left(\widehat{C R E}_{i, t-1} \times \widehat{U R}_{i, t-2}\right),\left(\widehat{C R E}_{i, t-2} \times \widehat{U R}_{i, t-3}\right)$ Standard instruments: $\triangle A R R_{i, t}, \Delta A R R_{i, t-1}, \Delta P M R_{i, t}, \Delta P M R_{i, t-1}, \Delta T W_{i, t}, \Delta C O R P_{i, t}, \Delta O G A P_{i, t}$ 
unemployment. This result is very robust across specifications and consistent with Nickell et al. (2005) and Bassanini and Duval (2006).

Second, we find a negative coefficient $\beta$ for the ratio of private credit by deposit money banks and other financial institutions to $\operatorname{GDP}\left(C R E_{i, t}\right)$. We interprete this coefficient as inversely related to the stringency of credit constraints. Let us notice, however, that $\beta$ would not be significantly different from zero in specification (14c). Estimates from specification (14b) suggest an explanation: when $U R_{i, t-1}$ is dropped, $C R E_{i, t}$ appears to be significantly different from zero, at the $1 \%$ level. This suggests that $C R E_{i, t}$ would affect the unemployment level directly, but also indirectly via its link with $U R_{i, t-1}$. Therefore our theory predicts that an increase in $C R E_{i, t}$ would significantly reduce the unemployment level. The estimated coefficient $\beta$ is significantly different from zero at the $10 \%$ level for specification (14d), with the expected negative sign.

In specification (14d), we find negative estimates $\gamma$ for the interaction term between $C R E_{i, t}$ and lagged unemployment $U R_{i, t-1}$. This suggests that the ratio of private credit by deposit money banks to GDP would significantly reduce the unemployment persistence at the $1 \%$ level, an evidence in line with the predictions of our theoretical model. Specification (14e) confirms the robustness of this result, controlling by the influence of employment protection on unemployment persistence. $^{10}$

The estimated vector $\kappa$ of parameters associated to standard unemployment determinants in the literature appears quite robust from specifications (14a) through (14e). Regarding labor market institutions, the average unemployment benefit replacement rate $\left(A R R_{i, t}\right)$ and the high-corporatism index $\left(C O R P_{i, t}\right)$ would affect the level of unemployment in a significant way, with the expected signs (respectively positive and negative). A more generous benefit system would tend to increase the level of unemployment, while a higher degree of coordination in wage-setting (as in Scandinavian economies, for instance) would reduce it. These results are consistent with Nickell et al. (2005) and Bassanini and Duval (2006). Moreover, they seem particularly robust to the introduction of our credit market development variable. The effect of union density $\left(U N D E N S_{i, t}\right)$ on unemployment does not seem very significant here. The tax wedge $\left(T W_{i, t}\right)$ appears as a significant factor of unemployment increase, which is in accordance with previous theoretical and empirical research. Employment protection legislation $\left(E P L_{i, t}\right)$, whose theoretical effects on unemployment are ambiguous (since it can decrease both unemployment entry and exit) appears to lower unemployment. The coefficient associated with rigidities in the goods market $\left(P M R_{i, t}\right)$ is significantly positive, which is consistent with previous research. Rents and other non-competitive features on the product market would tend to increase unemployment. The output gap measure $\left(O G A P_{i, t}\right)$ would significantly reduce unemployment. This index is computed as the difference between the actual output of an economy and its "full-

\footnotetext{
${ }^{10}$ It is worth noticing that estimates in Equations (14a), (14c), (14d) and (14e) correspond to contemporaneous effects, whereas estimates in Equation (14b) rather capture a long run effect. Given that estimates of the autoregressive coefficients $\alpha$ in Equations (14a), (14c), (14d) and (14e) are close to 3/4, one should approximately multiply by 4 estimates of $\beta$ and $\kappa$ to compare them with the corresponding estimates in Equation (14b).
} 
capacity" production potential, and thus has a negative sign. A negative coefficient associated with $O G A P_{i, t}$ implies that a reduction in the output gap reduces the unemployment level. This result is perfectly in line with Bassanini and Duval (2006). The introduction of $C R E_{i, t}$ and $\widehat{C R E}_{i, t} \times \widehat{U R}_{i, t-1}$ would not destabilize to a considerable extent estimates of coefficients $\kappa$.

We now deal with possible endogeneity issues, using instrumental approaches. Table 2 first provides estimates of specification (14d) using the two-stage least squares (2SLS) methodology. Reverse causality problems may potentially concern all variables in the right-hand side of (14d). However, since our particular focus is on credit market imperfections, we choose to be parcimonious and only instrument $C R E_{i, t}$ and $\widehat{C R E}_{i, t} \times \widehat{U R}_{i, t-1}$. The associated first-stage within regressions are available in Appendix D. Table 2 also displays estimates of Equation (14d) using the Arellano and Bond (1991) difference GMM. Interestingly, these two types of IV regressions provide consistent estimates as regards the influence of credit market imperfections on unemployment persistence.

The Sargan test evaluates regressor exogeneity for a panel data fixed-effects regression estimated via instrumental variables in which the number of instruments exceeds the number of regressors: that is, for an overidentified equation. If the associated p-value is equal or greater that $10 \%$, we can consider that the instruments are valid and not correlated to the error term, with a $10 \%$ error risk. According to this criterion, the regressions in Table 2 would display valid instruments, with a $10 \%$ error risk. Moreover, when the p-value associated to the ArellanoBond test for first-order autocorrelation is lower than 1\%, and the p-values for higher-order autocorrelation are greater than $10 \%$, we can conclude that disturbances in level equations are not autocorrelated with a $1 \%$ error risk, which means that appropriate instruments for the differenced equation are third and subsequent lags of $U R_{i, t}$. Our Arellano-Bond GMM estimation passes this test, which gives confirmation to the validity of our instruments.

To sum up, our instrumental estimations give further support to our quantitative findings. As additional checks for robustness, all our regressions were run on subsamples ignoring alternatively each country from the panel. We also performed estimations of specification (14d) by removing alternatively each component from the vector $X_{i, t}$ of standard unemployment determinants. These estimates, available upon request, tend to confirm our argument.

\section{Conclusion}

In this paper, we argue that credit market imperfections impact not only the level of unemployment, but also its persistence. For this purpose, we first develop our theoretical argument in a simple model based on the equilibrium matching framework of Mortensen and Pissarides (1999) and Pissarides (2000) where we introduce credit constraints. We show these credit constraints not only increase steady-state unemployment, but also slow down the transitional dynamics. We then provide an empirical illustration based on a macro-panel dataset of 20 OECD countries. 
Our results suggest that credit market imperfections would significantly increase the persistence of unemployment.

Some directions for further research naturally follow. First, we want to consider alternative measurements for the stringency of credit constraints. Second, we aim at generalizing the analysis to the case of endogenous job destruction. Third, we plan to investigate how the analysis would change with different other credit constraint specifications. We intend to pursue these projects in the soon future.

\section{References}

[1] Acemoglu, Daron (2001): "Credit Market Imperfections and Persistent Unemployment", European Economic Review, 45 (4-6), 665-679.

[2] Aghion, Philippe, Abhijit Banerjee and Thomas Piketty (1999): "Dualism and Macroeconomic Volatility", Quarterly Journal of Economics, 114 (4), 1359-1397.

[3] Arellano, Manuel and Stephen Bond (1991): "Some Tests of Specification for Panel Data: Monte Carlo Evidence and an Application to Employment Equations", Review of Economic Studies, 58, 277-297.

[4] Bassanini, Andrea and Romain Duval (2006): "Employment Patterns in OECD Countries: Reassessing the Role of Policies and Institutions", OECD Social, Employment and Migration Working Paper No. 35, and OECD Economics Department Working Paper No. 486, Paris.

[5] Belot, Michele and Jan C. Van Ours (2004): "Does the recent success of some OECD countries in lowering their unemployment rates lie in the clever design of their labor market reforms?", Oxford Economic Papers, 56 (24), 621-642.

[6] Beck, Thorsten, Asli Demirgüç-Kunt and Ross Levine (2000): "A New Database on Financial Development and Structure", World Bank Economic Review, 14, 597-605.

[7] Bernanke, Ben and Mark Gertler (1989): "Agency Costs, Net Worth, and Business Fluctuations", American Economic Review, 79 (1), 14-31.

[8] Bernanke, Ben, Mark Gertler and Simon Gilchrist (1999): "The Financial Accelerators in a Quantitative Business Cycle Framework", in John B. Taylor and Michael Woodford, eds., Handbook of Macroeconomics, 1341-1393.

[9] Bertola, Giuseppe, Francine Blau and Lawrence Kahn (2007): "Labor Market Institutions and Demographic Employment Patterns", Journal of Population Economics, 20 (4), 833867. 
[10] Blanchard, Olivier Jean and Justin Wolfers (2000): "The Role of Shocks and Institutions in the Rise of European Unemployment: the Aggregate Evidence", Economic Journal, 110 (March), C1-C33.

[11] Davidson, Russell and James McKinnon (1993): "Estimation and Inference in Econometrics", Oxford University Press, New York.

[12] Diamond, Peter (1982): "Wage Determination and Efficiency in Search Equilibrium", Review of Economic Studies, 49, 217-227.

[13] Gatti, Donatella and Anne-Gaël Vaubourg (2009): "Unemployment and Finance: How Do Financial and Labour Market Factors Interact?", IZA Discussion Paper No. 4075.

[14] Hristov, Atanas (2009): "Credit Frictions and Labor market dynamics", DIW Working Paper D.7.3.

[15] Kiyotaki, Nobuhiro and John Moore (1997): "Credit Cycles", Journal of Political Economy, $105(2), 211-248$

[16] Maillard, Michel (1997): "L'appariement des emplois vacants et du chômage en France", Economie et Prévision, 127, 157-163.

[17] Matsuyama,Kiminori (2007): "Credit Traps and Credit Cycles", American Economic Review, 97, 503-516.

[18] Mortensen, Dale and Christopher A. Pissarides (1994): "Job Creation and Job Destruction in the Theory of Unemployment", Review of Economic Studies, 61, 397-415.

[19] Mortensen, Dale and Christopher A. Pissarides (1999): "Job Reallocation, Employment Fluctuations and Unemployment", in John B. Taylor and Michael Woodford, eds., Handbook of Macroeconomics, 1171-1228.

[20] Nickell, Stephen, Luca Nunziata and Wolfgang Ochel (2005): "Unemployment in the OECD since the 1960s. What do we know?", Economic Journal, 115, 1-27.

[21] Petrongolo, Barbara and Chistopher.A. Pissarides (2001): "Looking into the Black Box: A Survey of the Matching Function", Journal of Economic Literature, 38, 390-431.

[22] Pissarides, Christopher A. (2000): "Equilibrium Unemployment Theory", $2^{\text {nd }}$ edition, Cambridge, MIT Press.

[23] Sargan, J. Denis (1958): "The Estimation of Economic Relationships Using Instrumental Variables", Econometrica, 26 (3), 393-415.

[24] Wasmer, Etienne and Philippe Weil (2004): "The Macroeconomics of Labour and Credit Market Imperfections," American Economic Review, 94, 944-963. 


\section{Appendix}

\section{A Unemployment Persistence under credit constraints}

Deriving (1) along the credit constrained regime where $\theta$ is given by JC gives:

$$
\begin{aligned}
\frac{\partial \dot{L}}{\partial L} & =-(\delta+\theta q(\theta))+\left.\frac{\partial \theta q(\theta)}{\partial \theta} \cdot \frac{\partial \theta}{\partial L}\right|_{\mathrm{JC}} \cdot(1-L) \\
& =-(\delta+\theta q(\theta))+q(\theta)(1-\eta(\theta)) \cdot \frac{\frac{\mu}{k} \frac{y-w}{\rho+\delta}-1}{1-L} \\
& =-(\delta+\theta q(\theta))+q(\theta)(1-\eta(\theta)) \cdot \frac{\theta}{L}
\end{aligned}
$$

where the second equality follows the derivation of (JC) and the last one from (JC)

\section{B Data sources, definitions description}

Aggregate unemployment rate (UR)

Definition: Unemployed workers in the age group 15-64 as share of the labor force (in \%).

Source : Bassanini and Duval 2006.

Average unemployment benefit replacement rate (ARR)

Definition: Average unemployment benefit replacement rate across two income situations (100\% and $67 \%$ of APW earnings), three family situations (single, with dependent spouse, with spouse in work) and three different unemployment durations (1st year, 2nd and 3rd years, and 4 th and 5th years of unemployment).

Source: Bassanini and Duval 2006.

High corporatism (CORP)

Definition: Indicator of the degree of centralization/coordination of the wage bargaining processes, which takes values 1 when wage bargaining is highly centralized or coordinated and 0 otherwise.

Source: Bassanini and Duval 2006

Union density (UNDENS)

Definition: Trade union density rate, i.e. the share of workers affiliated to a trade union, in $\%$.

Source: Bassanini and Duval 2006.

Labor tax wedge $(T W)$

Definition: Tax wedge between the labor cost to the employer and the corresponding net take-home pay of the employee for a single-earner couple with two children earning $100 \%$ of 
APW earnings. The tax wedge expresses the sum of personal income tax and all social security contributions as a percentage of total labor cost.

Source: Bassanini and Duval 2006.

Employment protection legislation ( $E P L)$

Definition: OECD summary indicator of the stringency of Employment Protection Legislation.

Source: Bassanini and Duval 2006.

Product market regulation (PMR)

Definition: OECD summary indicator of regulatory impediments to product market competition in seven non-manufacturing industries. The data cover regulations and market conditions in seven energy and service industries: gas, electricity, post, telecoms (mobile and fixed services), passenger air transport, railways (passenger and freight services) and road freight.

Source Bassanini and Duval 2006.

Output gap (OGAP)

Definition: OECD measure of the gap between actual and potential output as a percentage of potential output.

Source: Bassanini and Duval 2006.

Private credit by deposit money banks and other financial institutions to GDP (CRE)

Definition: $C R E$ equals claims on the private sector by both deposit money banks and other financial institutions divided by GDP. It measures isolate credit issued to the private sector as opposed to credit issued to governments and public enterprises. Furthermore, it concentrates on credit issued by intermediaries other than the central bank. It is a measure of the activity of financial intermediaries in one of its main function: channeling savings to investors.

Source: Beck, Demirgüç-Kunt and Levine 2001.

Public Ownership ( $P U B O W N$ )

Definition: $P U B O W N$ is a component of the OECD Product Market Regulation Index. It measures the scope of public enterprise, the size of public enterprise, special voting rights and the control of public enterprise by legislative bodies.

Source: Bassanini and Duval 2006. 
Table 3: Descriptive statistics of variables used in the analysis

\begin{tabular}{l|c|c|c|c|c}
\hline \hline Variable & Mean & $\begin{array}{c}\text { Standard } \\
\text { deviation }\end{array}$ & Minimum & Maximum & $\begin{array}{c}\text { Number of } \\
\text { observations }\end{array}$ \\
\hline UR (\%) & 7.76 & 4.27 & 0.45 & 24.04 & 369 \\
ARR (\%) & 29.88 & 12.82 & 0.35 & 64.94 & 369 \\
CORP & 0.54 & 0.50 & 0 & 1 & 369 \\
UNDENS (\%) & 39.04 & 20.57 & 8.6 & 83.73 & 369 \\
TW (\%) & 28.24 & 9.0 & 6.40 & 45.5 & 369 \\
EPL & 2.01 & 1.1 & 0.2 & 4.19 & 369 \\
PMR & 3.68 & 1.29 & 1.05 & 6 & 369 \\
OGAP & -0.68 & 2.40 & -10.72 & 6.30 & 369 \\
CRE & 0.94 & 0.39 & 0.25 & 2.11 & 369 \\
PUBOWN & 3.77 & 1.41 & 0.74 & 6 & 369 \\
\hline \hline
\end{tabular}

\section{Ranking country}

Table 4: Ranked credit index by country

\begin{tabular}{l|l}
\hline \hline Country & $\overline{C R E}_{i}$ \\
\hline \hline Japan & 1.621 \\
Switzerland & 1.538 \\
United States & 1.501 \\
Netherlands & 1.25 \\
Germany & 1.096 \\
United Kingdom & 1.04 \\
Sweden & 0.998 \\
Norway & 0.915 \\
Austria & 0.906 \\
Canada & 0.891 \\
France & 0.836 \\
New Zealand & 0.823 \\
Portugal & 0.814 \\
Spain & 0.786 \\
Irland & 0.749 \\
Australia & 0.633 \\
Finland & 0.63 \\
Italy & 0.59 \\
Denmark & 0.557 \\
Belgium & 0.517 \\
\hline \hline
\end{tabular}




\section{First-stage fixed-effects (within) regressions}

Table 5: Instruments used in the 2SLS estimates: first-stage regressions

\begin{tabular}{l|c|c}
\hline \hline & \multicolumn{2}{|c}{ Dependant Variable: } \\
& $C R E_{i, t}$ & $\widehat{C R E}_{i, t} \times \widehat{U R}_{i, t-1}$ \\
\hline \hline$U R_{i, t-1}$ & $-0.0073^{* * *}$ & $-0.21^{* * *}$ \\
$A R R_{i, t}$ & $(-3.03)$ & $(-7.59)$ \\
$C O R P_{i, t}$ & 0.00015 & -0.0098 \\
& $(0.13)$ & $(-0.75)$ \\
$U N D E N S_{i, t}$ & -0.018 & -0.13 \\
& $(-0.82)$ & $(-0.52)$ \\
$T W_{i, t}$ & -0.0012 & 0.0065 \\
$E P L_{i, t}$ & $(-1.11)$ & $(0.51)$ \\
$P M R_{i, t}$ & 0.00019 & 0.032 \\
& $(0.11)$ & $(1.64)$ \\
$P M R_{i, t-1}$ & -0.026 & $-0.70^{* * *}$ \\
$O G A P_{i, t}$ & $(-1.35)$ & $(-3.25)$ \\
PUBOW $N_{i, t-1}$ & -0.024 & -0.13 \\
& $(-0.95)$ & $(-0.45)$ \\
$C R E_{i, t-1}$ & 0.03 & $1.16^{* * *}$ \\
$C R E_{i, t-2}$ & $(1.06)$ & $(3.68)$ \\
Time dummies & 0.00047 & -0.040 \\
Country dummies & $(0.21)$ & $(-1.59)$ \\
Observations & -0.00099 & $-0.68^{* * *}$ \\
\hline \hline & $(-0.07)$ & $(-4.14)$ \\
& $1.34^{* * *}$ & $-4.06^{* * *}$ \\
& $(26.79)$ & $(-7.18)$ \\
& $-0.46^{* * *}$ & $1.17^{* *}$ \\
& $(-8.79)$ & $(1.96)$ \\
yes & no & no \\
& 369 & 369 \\
\hline
\end{tabular}

